\title{
Effect of Cooperative Learning Approach on Recycling Sensitiveness of Preservice Classroom Teachers
}

\author{
Seçil ERÖKTEN, Asiye BAHTIYAR \\ Pamukkale University, Faculty of Education, Science Education Dept., Denizli, Turkey
}

\begin{abstract}
To prevent today's increasing environmental problems is only possible with an effective environment education. Teachers, in turn preservice teachers have great responsibility to enable an effective environment education. Therefore, this research aimed to determine the effect of cooperative learning method which is implemented in Environment Education course on preservice classroom teachers' sensitiveness about recycling. One group pretest-posttest experimental design was used fort his aim. A total of $1002^{\text {nd }}$ grade students enrolling Classroom Teaching Departments and attending Environment Education course in 2016-2017 academic year, fall semester participated in the research. As a data collection tool, "Sensitivity Survey of Environmental Recycling" was used. The reliability coefficient was calculated as .849. In order to test whether the data was normally distributed or not, Kolmogorov-Smirnov analysis was used and results showed the data was normally distributed. In this research, paired samples t-test, independents samples t-test and one way ANOVA were used as parametric tests. There was a statistically significant difference between the mean scores of pretest and posttest of preservice classroom teachers on behalf of post-test. Comparing the posttests' scores according to gender, there was a significant difference on behalf of girls, and there was no difference according to age. The sensitiveness of preservice classroom teachers about recycling did not differ according to high school type and residential area in which they live the longest.
\end{abstract}

Keywords - Cooperative learning, Preservice classroom teachers, Environment education, recycling, Sensitiveness

\section{INTRODUCTION}

Rapid increase in population, unplanned urbanization, corruption of wild life, global warming, hole in ozone layer, greenhouse effect, nuclear pollution, decrease in green areas, extinction of plant and animal species are among the main environmental problems today. Particularly, as a natural consequence of rapid and unplanned urbanization, one of the environmental problems which has become an important issue in recent years and has threaten the human future is the problem of solid waste, and this problem is increasing day by day (Mert, 2006; Kışoğlu and Yıldırım, 2015).Wastes such as glass, plastic, paper and metal stay in nature many years and this gives rise to visual pollution, environmental pollution and various illnesses. Apart from this, an economical loss arises as a result of not separating these materials at home and institutions, and not collecting them in order to reutilize (Mert, 2006; Özbay, 2010). To prevent this loss, solid wastes are required to be collected, carried, stored and harmlessly reutilized as an effective, productive and ordered way (Mert, 2006).

Recycling is a reutilization of materials such as plastic, glass, metal, paper and carton in solid wastes that undergo a physical, chemical and biological process, and a secondary product and raw material are obtained from them (Yücel, 1997). Materials such as metal, glass, plastic and paper stay in nature very long time without corruption, and they are the top consumed but easily recycled materials. Moreover, the amount of energy consumed during the recycling process is much more less than the amount of energy consumed during obtaining a product from a raw material. Owing to the recycling of these materials, the need for raw material decreases and natural resources will be protected; extra energy consumption will be prevented by means of reutilization of recycling materials as raw materials, and solid waste mass decreases (Keser, 2008; Özbay, 2010).

Environmental problems can not be solved only by technology and regulations but the changes in behaviors of individuals (Erten, 2004). Therefore, it is required to separate the recyclable packaging wastes at home, offices and schools and for municipalities to collect them due to prevent the environmental pollution, and moreover individuals should be willing for recycling (Bakar and Aydınl, 2012). In this context, individuals have important duties and responsibilities for decreasing the waste production, separating the wastes, classifying and collecting the solid wastes according to their properties and sending them to recycling. At home, packaging wastes such as glass, paper, carton, metal and plastic and food waste should be collected separately. Batteries should not be regarded as a waste and be collected in a separate place. Recycling the solid wastes by collecting them consciously not only decreases the environmental pollution but also contribute to economy (Çevre Bakanlığı, 1995; Pamukçu, 1995; Karatekin, 2013). 
To train conscious, sensitive and aware individuals who have these duties and responsibilities, and to construct positive attitudes and values towards environment in society can only be possible by environment education (Erten, 2004; Karatekin, 2013). This education provides a positive attitude and behavior pattern towards the protection of environment for individuals' consumption habits and sustainable usage of natural resources; besides it contributes to have gain knowledge and awareness about the protection of environment. A planned and continuous perspective of environment education from primary school to college makes an individual more sensitive and conscious. Moreover, it gains him/her perpetual behaviors without destroying the natural balance while s/he is making benefit from the environment (Çolakoğlu, 2010).

With reference to the statement "as the twig is bent, so is the tree inclined", to construct experiences by creating an awareness for children in early ages and increase their sensitiveness might be possible by recycling which is an important basement of environment education (Şallı, et al., 2013). Considering the significance of teachers who play an active role for an effective environment education and who create a sensitiveness and positive attitudes towards the protection of environment; it is extremely important for a teacher to have enough knowledge, positive attitude and behavior about the issue (Kahyaoğlu and Kaya, 2012).

Examining the recent body of research about environment, there are many one of which developed environmental sensitiveness scale (Metzger and Mcewen, 1999); made a meta-analysis of scales developed on environmental paradigms in the late 30 years (Hawcroft and Milfont, 2010); found positive effects of nature documentaries on students' environmental sensitiveness (Barbas, Paraskevopoulos and Stamou, 2009), studied the views of students and teachers on aims of the environment science course (Blatt, 2015); presented the views of academicians on environmental sustainability in higher education (Christie, Miller, Cooke and White, 2015); reviewed the environmental curriculum in new era (Stern, Powell and Hill, 2014); and determined the environmental attitudes of preservice teachers (Watson and Halse, 2005).

In a research which examined the cooperative learning approach in environment education course, quite positive results were reached such that jigsaw technique increases the academic achievement, develops the thinking skills, draws attention to subject matter, develops the quality and frequency of communication among both group mates and the teacher, supports a democratic relationship with the teacher, encourages a preparation for the course, and has a positive impact on self-expression of students (Gürbüz, Çakmak and Derman, 2012). Furthermore, station technique is seemed to be funny, attractive, instructive, increases the creativity and imagination, helps cooperative study, provides a rapid and practical thinking and helps to learn from the others' perspectives (Genç, 2013); jigsaw technique has a positive effect on preservice teachers' academic achievement, attitudes toward environmental problems and permanence on learning (Uyanı, 2016).

In literature on environment education and recycling which was conducted with preservice teachers, preservice teachers thought recycling as an universal activity, and stated that recycling should be considered as an individual's responsibility to protect the environmental pollution, recycling boxes should be used and industry sector have the responsibility of using recycling materials (Yücel and Morgil, 1998; Kahyaoğlu and Kaya, 2012; Kocalar and Balc1, 2013). On the other hand, according to the results of some research, a part of preservice teachers think that there is no effort on separating the wastes for recycling (Yildirım, Bacanak and Özsoy, 2012); they have a low awareness level of solid waste and recycling (Karatekin, 2014); and they don't show enough sensitiveness for recycling even though they have enough knowledge about what recycling is and which materials are recycled (Demircioğlu, Demircioğlu and Yadigaroğlu, 2015).

Examining the literature as a whole and in a detailed way, preservice teachers are aware of the importance and requirements of recycling however they don't show enough responsibility to be sensitive for this issue. Considering the importance of education on training sensitive individuals about recycling, the significance of developing the sensitiveness of preservice classroom teachers about recycling who train students becomes required. In this context, it becomes also important to make implementations to construct an awareness and sensitiveness for environment and recycling in learning environment of preservice classroom teachers.

In this research it is aimed to determine the effect of cooperative learning method implemented in Environment Education course on 2nd grade preservice classroom teachers' sensitiveness about recycling. Moreover, the sensitiveness of preservice classroom teachers on recycling is examined according to their demographics.

\section{METHODOLOGY}

\subsection{Research Model}

One group protest-posttest experimental design was used in the research. In this design, the effect of experimental process is tested by a study on one group. The assessments of subjects in terms of dependent variable are achieved using same assessment tools and same subjects via pretest before the experiment and posttest after the experiment (Büyüköztürk, et al., 2012).

\subsection{Study Group}


The universe of the study is the students attending Classroom Teaching Department of Faculty of Education in Pamukkale University in fall semester of 2016-2017 academic years. The sample of the study consists of 100 2nd grade students enrolling Environment Education course.

Of the participants, 75 of them were girls $(75 \%)$ and 25 of them were male $(25 \%)$; with ages of 18 (39\%), 19 and above (61\%). Participants graduated from Anatolian High School (50\%), Anatolian Teacher High School (15\%), High School (15\%) and other types of high schools such as science high school, technical high school etc.- $(20 \%)$. They indicated their residential area in which they live the longest as villages (15\%), town (7\%), county (34\%), city (14\%) and metropolis (30\%).

\subsection{Data Collection Tool}

"Environmental Recycling Sensitiveness Scale" developed by Aksakal (2013) was used in the study. As a 34 item scale, it has positive and negative items ranging in a 5 likert type. The negative items are 7, 14, 17, 18, 19 and 32; the rests are positive items. The reliability coefficient of the scale is .72 .

In data collection process, first of all, all students were informed about the implementation of cooperative learning method in Environment Education course. Secondly, students are classified in nine groups and subjects about the environment (air, water, earth, radioactive, sight, noise pollution, greenhouse effect, global warming, acid rains, recycling, and reutilizations of waste, alternative energy resources, environmental sensitiveness, and research on environmental sensitiveness) were shared among the groups. Data collection tool was implemented to the volunteered participants before and after the experiment.

\subsection{Data Analysis}

Positive items in the scale were ranged from 5 (totally agree) to 1 (totally disagree); negative items were ranges vice versa. The reliability of the scale was calculated as .849. Kolmogorov-Smirnov analysis was used in order to understand whether the data was normally distributed and the results showed a normal distribution $(Z=0,475 ; p>0,05)$. Paired samples t-test, Independent samples t-test and One-Way ANOVA were used for the analysis.

\section{FINDINGS}

Table 1 displays the findings of Paired Samples t-Test implemented to determine the recycling sensitiveness of preservice classroom teachers before and after Environment Course in which cooperative learning method was implemented.

Table 1. Pretest and Posttest Scores from Recycling Sensitiveness Scale

\begin{tabular}{|c|c|c|c|c|c|c|}
\hline Variable & Category & $\mathbf{N}$ & $\bar{X}$ & $\mathbf{S d}$ & $\mathbf{t}$ & $\mathbf{p}$ \\
\hline Recycling & PreTest & 100 & 3,5074 &, 41152 & $-3,077$ & \multirow{2}{*}{$003^{*}$} \\
\cline { 2 - 5 } Sensitiveness & PostTest & 100 & 3,6759 &, 40204 & & \\
\hline
\end{tabular}

$* \mathrm{p}<0,05$

There is a statistical difference between the pretest and posttest scores of preservice teachers from Recycling Sensitiveness Scale ( $\mathrm{t}=-3,077 ; \mathrm{p}<0,05)$. The posttest mean scores of preservice classroom teachers ( $=3,68)$ is pretty much higher than the pretest mean scores $(=3,51)$.

The findings of Independent Samples t-Test made to determine whether the recycling sensitiveness of preservice classroom teachers significantly differ according to their gender and ages are shown in Table 2.

Table 2. Independent Samples t-Test Showing Whether Recycling Sensitiveness Scale Scores Differ According to Gender and Age

\begin{tabular}{|c|c|c|c|c|c|c|}
\hline \multirow{2}{*}{ Variable } & Category & $\mathbf{N}$ & $\bar{X}$ & $\mathbf{S d}$ & $\mathbf{t}$ & $\mathbf{p}$ \\
\hline \multirow{2}{*}{ Gender } & Female & 75 & 3,75 &, 370 & \multirow{2}{*}{3,266} & \multirow{2}{*}{, $002^{*}$} \\
\cline { 2 - 5 } & Male & 25 & 3,46 &, 423 & & \\
\hline \multirow{2}{*}{ Age } & 18 & 39 & 3,6817 &, 46772 & \multirow{2}{*}{, 116} & \multirow{2}{*}{, 908} \\
\cline { 2 - 5 } & 19 and above & 61 & 3,6721 &, 35792 & & \\
\hline
\end{tabular}

$* \mathrm{p}<0.05$

According to the analysis, there is a statistically significant difference of preservice teachers' recycling sensitiveness in terms of their gender $(t=3,266 ; \mathrm{p}<0,05)$. Examining the mean scores, females get higher scores $(=3,75)$ than males $(=3,46)$. There is no significant difference of preservice teachers' recycling sensitiveness in terms of their age $(t=3,46 ; p>0,05)$. 
Table 3 displays the findings of One Way ANOVA made to determine whether the recycling sensitiveness of preservice classroom teachers significantly differ according to high school type graduated and the residential area where they live the longest.

Table 3. One Way ANOVA Showing Whether Recycling Sensitiveness Scale Scores Differ According to High School Type and Residential Area

\begin{tabular}{|c|c|c|c|c|c|c|}
\hline & $\begin{array}{l}\text { Source of } \\
\text { Variance }\end{array}$ & $\begin{array}{l}\text { Sum of } \\
\text { Squares }\end{array}$ & df & $\begin{array}{c}\text { Mean } \\
\text { Squares }\end{array}$ & $\mathbf{F}$ & $\mathbf{P}$ \\
\hline \multirow{3}{*}{$\begin{array}{l}\text { High } \\
\text { School } \\
\text { Type }\end{array}$} & Between Groups & , 108 & 3 & ,036 & \multirow[t]{3}{*}{,218 } & \multirow[t]{3}{*}{,883* } \\
\hline & Within Groups & 15,893 & 96 & , 166 & & \\
\hline & Total & 16,002 & 99 & & & \\
\hline \multirow{3}{*}{$\begin{array}{l}\text { Residential } \\
\text { Area }\end{array}$} & Between Groups & ,595 & 4 & , 149 & \multirow[t]{3}{*}{,917 } & \multirow[t]{3}{*}{,457* } \\
\hline & Within Groups & 15,407 & 95 & , 162 & & \\
\hline & Total & 16,002 & 99 & & & \\
\hline
\end{tabular}

The findings show no significant differences of preservice classroom teachers' recycling sensitiveness in terms of high school type graduated and residential area where they live the longest (Fhighschool=0,218; $>0,05$ ); Fresarea $=0,917 ; p>0,05$ ).

\section{CONCLUSION, DISCUSSION AND SUGGESTION}

In this research, which studied the effect of cooperative learning in Environment Course on recycling sensitiveness of preservice classroom teachers, it has been also studied whether the recycling sensitiveness of preservice classroom teachers differ according to demographics variables. Analysis showed a positive change on the recycling sensitivity of 2 nd grade preservice classroom teachers after the implementation of cooperative learning method in Environment Education course. These results are consistent with the related literature which examined the jigsaw and station techniques in Environment Education course and found that these techniques have a positive impact on the attitudes of preservice teachers towards environmental problems (Gürbüz, Çakmak and Derman, 2012; Genç, 2013; Uyanık, 2016). Female preservice teachers are found to be more sensitive to recycling than are males. Although this difference is thought to be because of the gap in the numbers of two genders, there is some research found a significant difference in terms of females about environmental sensitiveness (Çabuk and Karacaoğlu, 2003; Şama, 2003; Çimen, Y1lmaz and Çimen, 2011); nevertheless there are some others which showed no significant difference according to gender in terms of environmental sensitiveness (Kahyaoğlu, Daban and Yangın, 2008; Server and Yalçınkaya, 2012; Ercengiz, Keçeci Kurt and Polat, 2014). There is no significant difference between the recycling sensitiveness of classroom preservice teachers according to their ages, high school type graduated and residential area where they live the longest. The reason why preservice teachers' sensitiveness do not differ according to their ages might be that they are in similar ages. Alongside, there are similar studies that reached the same results (Çabuk and Karacaoğlu, 2003; Ercengiz, Keçeci Kurt and Polat, 2014). Related literature support the findings about high school type graduated (Kayhaoğlu, Daban and Yangın, 2008). Moreover, this might be because of that there are not any various implementations in different types of high schools about the environmental and recycling sensitiveness of students. There is some research suggesting that there is no significant difference of preservice teachers' environmental sensitiveness in terms of residential area where they live the longest (Ercengiz, Keçeci Kurt and Polat, 2014), besides there are some others which stated that the attitude levels of preservice teachers who live in metropolis the longest are higher than the ones who live in smaller places (Şama, 2003).

At this point, what important is to determine the reasons of these results and qualitative studies are taken into consideration in this context.

\section{REFERENCES}

[1] Mert, M. (2006). Lise öğrencilerinin Çevre Ĕ̆itimi ve Katı Atıklar Konusundaki Bilinç Düzeylerinin Saptanması, Yüksek Lisans Tezi, Hacettepe Üniversitesi, Eğitim Bilimleri Enstitüsü, Ankara.

[2] Kışoğlu, M. ve Yıldırım, T. (2015). İlkokul ve ortaokullarda çevre eğitimi verecek olan öğretmen adaylarının katı atıklar ve geri dönüşüme yönelik tutumlarının farklı değişkenler açısından incelenmesi. International Journal of Human Sciences, Volume:12, Issue: 1, p. 1518-1536.

[3] Özbay, Ş. (2010). Fen ve Teknoloji Programı İçinde Kompost Hakkında Verilen Etkinliklerin Öğrencilerin Akademik Başarılarına ve Çevre Tutumlarına Etkisi, Yüksek Lisans Tezi, Onsekiz Mart Üniversitesi Fen Bilimleri Enstitüsü, Çanakkale 
[4] Yücel, K. (1997). Türkiye’de Katı Atık Yönetimi ve Geri Kazanım, Bilim Uzmanlığı Tezi, Yıldız Teknik Üniversitesi Fen Bilimleri Enstitüsü, İstanbul.

[5] Keser, S. (2008). Fen Bilgisi Öğretmen Adaylarının Çevreye Karşı Tutumu, Yüksek Lisans Tezi, Abant İzzet Baysal Üniversitesi, Sosyal Bilimler Enstitüsü, İlköğretim Bölümü, Fen Bilgisi Öğretmenliği Anabilim Dalı, Bolu

[6] Erten, S. (2004). Çevre Eğitimi ve Çevre Bilinci Nedir, Çevre Eğitimi Nasıl Olmalıdır? Çevre ve İnsan Dergisi, Çevre ve Orman Bakanlığı Yayın Organı. Sayı 65/66. 2006/25 Ankara

[7] Bakar, F. ve Aydınlı, B. (2012). Bilim ve Sanat Merkezi Öğrencilerinin Plastik ve Plastik Atıkların Geri Dönüşümü ve Çevreye Etkileri Konularında Tutumlarının Belirlenmesi (Batı Karadeniz Bölgesi Örneklemi), X. Ulusal Fen Bilimleri ve Matematik Eğitimi Kongresi. Niğde: Niğde Üniversitesi

[8] Çevre Bakanlığı (1995). Aile ve Çevre, Çevre Yazıları, T.C Çevre Bakanlığı Yayınları, Ankara, 14 -38 s.

[9] Pamukçu, F. N. (1995). Evsel Atıkların Yönetimi ve Geri Kazanılması, T.C Çevre Bakanlığı Yazıları, Ankara, 7s.

[10] Karatekin, K. (2013). Öğretmen Adayları için Katı Atık ve Geri Dönüşüme Yönelik Tutum Ölçeğinin Geliştirilmesi: Geçerlik ve Güvenirlik Çalışması, Uluslararası Avrasya Sosyal Bilimler Dergisi, 4 (10): 71-90

[11] Çolakoğlu E, (2010). Haklar Söyleminde Çevre Eğitiminin Yeri ve Türkiye'de Çevre Eğitiminin Anayasal Dayanakları, Atatürk Üniversitesi İktisadi ve İdari Bilimler Fakültesi, TBB dergisi, sayı 88. Erzurum

[12] Şallı, D., Doğal, A. B., Küçükoğlu, E. K., Niran, Ş. S. ve Tezcan, G. (2013). Okul Öncesinde Geri Dönüşüm Kavramı: Aile Katılımlı Proje Tabanlı Bir Program Örneği, Eğitim ve Öğretim Araştırmaları Dergisi, 2 (2): 234-241.

[13] Kahyaoğlu, M. ve Kaya, M. F. (2012). Öğretmen Adaylarının Çevre Kirliliğine ve Çevreyle İlgili Sivil Toplum Örgütlerine Yönelik Görüşleri, Ĕ̈itim Bilimleri Araştırmaları Dergisi, 2 (1): 91-107.

[14] Metzger, T. \& Mcewen, D. (1999). "Measurement of Environmental Sensitivity." The Journal of Environmental Education, 30(4), 38-39. http://dx.doi.org/10.1080/ 00958969909601883.

[15] Hawcroft, L. J. \& Milfont, T. L. (2010). "The Use (and Abuse) of The New Environmental Paradigm Scale over the Last 30 Years: A meta-analysis.” Journal of Environmental Psychology, 30, 143-158. http://dx.doi.org/10.1016/j.jenvp.2009.10.003

[16] Barbas, T. A., Paraskevopoulos, S. \& Stamou, A. G. (2009). "The Effect of Nature Documentaries on Students' Environmental Sensitivity: A Case Study." Learning, Media and Technology, 34(1), 61-69. http://dx.doi.org/10.1080/17439880902759943

[17] Blatt, E. N. (2015). "An Investigation of the Goals for an Environmental Science Course: Teacher and Student Perspectives.”, Environmental Education Research, 21(5), 710-733. http://dx.doi.org/10.1080/13504622.2014.918935

[18] Christie, B. A., Miller, K. K., Cooke, R. \& White, J. G. (2015). "Environmental Sustainability in Higher Education: What Do Academics Think?" Environmental Education Research 21(5), 655-686. http://dx.doi.org/10.1080/13504622.2013.879697

[19] Stern, M. J., Powell, R. B. \& Hill, D. (2014). "Environmental Education Program Evaluation in The New Millennium: What Do We Measure and What Have We Learned?", Environmental Education Research, 20(5), 581-611.

[20] Watson, K. \& Halse, C. M. (2005). "Environmental Attitudes of Pre-Service Teachers: A Conceptual and Methodological Dilemma in Cross-Cultural Data Collection." Asia Pacific Education Review, 6(1), 5971

[21] Gürbüz, H., Çakmak, M. ve Derman, M. (2012). Çevre Eğitiminde Jigsaw Tekniği Kullanımının Öğrencilerin Akademik Başarısına Etkisi ve Öğrencilerin Bu Tekniğe İlişkin Görüşleri. Karadeniz Sosyal Bilimler Dergisi, 4 (7), 1-13.

[22] Genç, M. (2013). Çevre Eğitiminde İstasyon Tekniğinin Kullanılması Hakkında Öğretmen Adaylarının Görüşleri. Erzincan Üniversitesi Eğitim Fakültesi Dergisi, Cilt-Sayı:15-2.

[23] Uyanık, G. (2016). Birleştirme tekniğine dayalı öğretimin çevre sorunlarına yönelik tutum akademik başarı ve kalıcılığa etkisi. Turkish Journal of Education (TURJE), Volume 5, Issue 2, 60-71.

[24] Yücel, A. S. ve Morgil, F. İ. (1998). Yüksek Öğretimde Çevre Olgusunun Araştırılması, Hacettepe Üniversitesi, Eğitim Fakültesi Dergisi, 14: 84-91

[25] Kocalar, A. O. ve Balcı, A. (2013). Coğrafya Öğretmen Adaylarının Çevre Okuryazarlılık Düzeyleri, International Journal Social Science Research, 2 (1): 15-49.

[26] Yıldırım, C., Bacanak, A. ve Özsoy, S. (2012). Öğretmen Adaylarının Çevre Sorunlarına Karşı Duyarlılıkları, Kastamonu Ĕgitim Dergisi, 20 (1): 121-134

[27] Karatekin, K. (2014). Social Studies Pre-Service Teachers' Awareness of Solid Waste and Recycling, Procedia - Social and Behavioral Sciences, 116: 1797-1801. 
[28] Demircioğlu, G., Demircioğlu, H. ve Yadigaroğlu, M. (2015). Fizik, Kimya ve Biyoloji Öğretmen Adaylarının Çevre Bilinç Düzeylerinin Değerlendirilmesi, Adıyaman Üniversitesi Sosyal Bilimler Enstitüsü Dergisi, 8 (19): 167-193.

[29] Büyüköztürk, Ş., Kılıç Çakmak, E., Akgün, Ö. E., Karadeniz, Ş. ve Demirel, F. (2012). Bilimsel Araştırma Yöntemleri (Geliştirilmiş 12. Baskı). Ankara: Pegem Akademi.

[30] Aksakal, Ş. (2013). Fen ve Teknoloji Dersi Öğretmen Adaylarının Çevresel Geri Dönüşüm Konusunda Duyarlılıklarının Belirlenmesi, Yüksek Lisans Tezi, Fırat Üniversitesi, Eğitim Bilimleri Enstitüsü, İlköğretim Anabilim Dalı, Elazı̆̆.

[31] Çabuk, B. ve Karacaoğlu, Ö.C. (2003). Üniversite Öğrencilerinin Çevre Duyarlılıklarının İncelenmesi. Ankara Üniversitesi Ĕ̈itim Bilimleri Fakültesi Dergisi, Cilt 36, Sayı 1-2.

[32] Şama, E. (2003). Öğretmen Adaylarının Çevre Sorunlarına Yönelik Tutumları. G.Ü. Gazi Eğitim Fakültesi Dergisi, Cilt 23, Say1 2, 99-110.

[33] Çimen, O., Yılmaz, M. ve Çimen, G. (2011). Biyoloji Öğretmen Adaylarının Çevre Duyarlı Davranışlarının Çeşitli Değişkenlere Göre İncelenmesi. Selçuk Üniversitesi Ahmet Keleşoğlu Ĕğitim Fakültesi Dergisi, Sayı 32, Sayfa 191-201.

[34] Kahyaoğlu, M., Daban, Ş. ve Yangın, S. (2008). İlköğretim Öğretmen Adaylarının Çevreye Yönelik Tutumları. Dicle Üniversitesi Ziya Gökalp Eğitim Fakültesi Dergisi, 11, 42-52.

[35] Sever, R. ve Yalçınkaya, E. (2012). Sınıf Öğretmeni Adaylarının Çevresel Tutumlarının İncelenmesi. Marmara Coğrafya Dergisi, Say1: 26, S. 1-15.

[36] Ercengiz, M., Keçeci Kurt, S. ve Polat, S. (2014). Öğretmen Adaylarının Çevre Sorunlarına Yönelik Duyarlılıklarının İncelenmesi (Ağrı İli Örneği). EKEV Akademi Dergisi, Sayı 59, Sayfa 119-132. 